\title{
Histological and Histochemical Changes by Clove Essential Oil Upon the Gonads of Spodoptera frugiperda (JE Smith) (Lepidoptera: Noctuidae)
}

\author{
Alteraciones Histológicas e Histoquímicas Provocadas por el Aceite Esencial de Clavo de Olor \\ en las Gónadas de Spodoptera frugiperda (JE Smith) (Lepidoptera: Noctuidae)
}

Glaucilane dos Santos Cruz*; Valeria Wanderley Teixeira*; Jose Vargas de Oliveira**; Alvaro Aguiar Coelho Teixeira*; Alicely Correia Araújo*; Thiago Jose de Souza Alves*; Franklin Magliano da Cunha* \& Mariana Oliveira Breda**

CRUZ, G. S.; TEIXEIRA, V. W.; DE OLIVEIRA, J. V.; TEIXEIRA, A. A. C.; ARAÚJO, A. C.; ALVES, T. J. S.; DA CUNHA, F. M. \& BREDA, M. O. Histological and histochemical changes by clove essential oil upon the gonads of Spodoptera frugiperda (JE Smith) (Lepidoptera: Noctuidae). Int. J. Morphol., 33(4):1393-1400, 2015.

SUMMARY: Spodoptera frugiperda is a polyphagous insect that causes economic losses to several crops in Brazil and is the major obstacle to corn production. Researches focusing on alternative control, e.g. botanical products are expanding to offer a wide variety of molecules that interfere with different biological parameters of insect pests. Thus, this study tested the hypothesis that clove essential oil affects the spermatogenesis, ovarioles histochemistry and the fertility of S. frugiperda. The results showed that clove essential oil affects the gametogenesis of S. frugiperda ovarioles, reflecting negatively on its reproduction, proving to be a promising tool for controlling this pest.

KEY WORDS: Fall armyworm; Spodoptera frugiperda; Reproduction; Histochemistry; Histology; Syzygium aromaticum.

\section{INTRODUCTION}

The importance of the fall armyworm, Spodoptera frugiperda (JE Smith) (Lepidoptera: Noctuidae), is not only due to its damage, but mainly to the difficulties in its control, which demands high number of synthetic insecticides applications, such as pyrethroids, organophosphates and urea derivatives (Cruz et al., 1999). The continued use of such products, besides several side effects, including biological imbalances, death of pollinating insects and food residues; is leading this pest to develop a pre-adaptive and hereditary resistance, increasing the need to investigate promising alternatives control that minimize the adverse effects of synthetic insecticides (Lima et al., 2009).

The search for new control methods includes the use of secondary plant metabolites, as several substances derived from plants have shown efficacy in pest control, exertingdifferent biological effects, such as repellency, feeding and growth inhibition, changes in the hormonal system, morphogenetic changes, disturbances in sexual behavior, sterilization, mortality in immature or adult stage, reduced fecundity and fertility, among others (Isman, 2006; Gallegos \& \& Maroneze, 2009).

Several essential oils with insecticidal properties have been evaluated on biological, physiological and behavioral parameters upon moths of the genre Spodoptera demonstrating the potential of these substances on pest control. Among the essential oils investigated, the clove, Syzygium aromaticum (Myrtaceae), is majorly constituted of Eugenol, an aromatic compound exhibiting proven antibacterial, antimycotic, antiinflammatory, anesthetic, antiseptic, antioxidant, allelopathic, repellent and insecticide activities (Oliveira et al., 2007; Silvestri et al., 2010). However, researches that focus on histopathological changes in the gonads of insects are quite restricted to synthetic insecticides (Shehata et al., 2006; Habluetzel et al., 2007; Senthil Nathan et al., 2008), and when addressing to essential oils, are restricted to the use of azadirachtin and Piper hispidinervum (Abdel-Rahman et al., 2004; Alves et al., 2014).

\footnotetext{
* Department of Animal Morphology and Physiology, Federal Rural University of Pernambuco, Recife, Brazil.

** Department of Agronomy Department, Federal Rural University of Pernambuco, Recife, Brazil. Sponsorship: CNPq
} 
Therefore, this study aimed to evaluate the effects of clove essential oil, in sublethal concentrations, on the spermatogenesis and histochemistry of $S$. frugiperda ovarioles, thereby determining potential interferences upon its fertility, which may lead to reduced population and consequently, reduced damage to the target crop.

\section{MATERIAL AND METHOD}

Our study was conducted at the Histology Laboratory of the Department of Animal Morphology and Physiology and the Agricultural Entomology Laboratory in the Department of Agronomy at the Rural Federal University of Pernambuco (UFRPE).

Insect Rearing. Larvae of S. frugiperda were obtained from the rearing stock at the Agricultural Entomology laboratory and maintained at $25.2 \pm 1.4{ }^{\circ} \mathrm{C}$, relative humidity $67 \pm 0.7 \%$ and a photoperiod of $12 \mathrm{~h}$. The larvae were fed with leaves of AG 1051 double hybrid corn. The corn plants were cultivated in a greenhouse, two plants/51 pot with soil mixed with worm humus in the proportion of $2: 1$ plus $12.13 \mathrm{~g}$ of NPK (4:14:8 formulation).

Obtaining Essential Oil. The clove was purchased from commercial houses of spices in the city of Recife, PE, and at the Laboratory of Bioactive Natural Products, Chemistry Department (UFRPE), was submitted to hydrodistillation for $2 \mathrm{~h}$. The essential oil was extracted using a Clevenger type apparatus. After draining the water, the extract was dried using anhydrous $\mathrm{Na}_{2} \mathrm{SO}_{4}$ and stored at low temperature in a dark, hermetically sealed container.

Phytotoxicity Test. A preliminary trial was carried out to test the phytotoxicity of clove oil, using concentrations of $1000,500,250,125,60,50$ and $30 \mathrm{mg} / 100 \mathrm{ml}$ distilled water. Ten pieces of corn leaf, approximately $8.0 \times 4.5 \mathrm{~cm}$, were used for each concentration; each piece represented a repetition. The leaves were dipped for $10 \mathrm{sec}$ in the test emulsions, then dried on a paper towel. The phytotoxicity level for each piece of leaf was assessed according to the size of burned areas, and classified as mild, moderate or severe using a percentage scale for phytotoxicity adapted from Frans et al. (1986). The mild phytotoxicity level was used for testing the bioactivity of clove oil.

Bioassays. Pieces of leaves of 20-40-day-old corn, approximately $6.0 \times 4.5 \mathrm{~cm}$, were immersed in either the 30 or $50 \mathrm{mg} / \mathrm{L}$ clove oil. The control leaves were immersed in DMSO only, $2 \mathrm{ml}$ in $98 \mathrm{ml}$ distilled water. After soaking for 10sec, each leaf piece was allowed to dry and offered to 10day-old S. frugiperda larvae (3rd instar; average weight of $78.15 \mathrm{mg}$ ) for $48 \mathrm{~h}$, long enough for them to consume the entire leaf. These larvae subsequently were fed with pieces of untreated leaves, replaced daily, until the pupa stage. Each treatment consisted of 150 individual larvae in 80 plastic containers with threaded lids. The testes from 10 male insects were collected at the last larval instar stage. Ovarioles were collected from 10 females $24 \mathrm{~h}$ of emerged larvae. The remaining adults were fed with a $10 \%$ honey solution, replaced daily, and the total number of eggs and viable eggs were counted. All treatments were carried out in a chamber at $25.2 \pm 1.4{ }^{\circ} \mathrm{C}$, relative humidity $67 \pm 0.7 \%$ and a photoperiod of $12 \mathrm{~h}$. Bioassays were carried out in duplicate.

Gonad histology and histochemistry. The gonads were fixed in $10 \%$ formalin for $24 \mathrm{~h}$ after collection. They subsequently were dehydrated through an ethanol series (70, 80 and $95 \%$ ) for 10 min each, and impregnated with and embedded in Historesin. The blocks were sectioned using a Minot microtome (LEICA RM 2035) and sections were stained with toluidine blue and Mallory trichrome to detect connective tissue, periodic acid-Schiff (PAS) to detect neutral carbohydrates, and bromophenol blue to detect proteins. Stained sections were examined using a light microscope (Olympus BX-49). Photos were taken with a camera (Olympus BX-51) mounted on the microscope.

Total number of eggs and number of viable eggs. Each replication consisted of a pair of adult insects kept in PVC
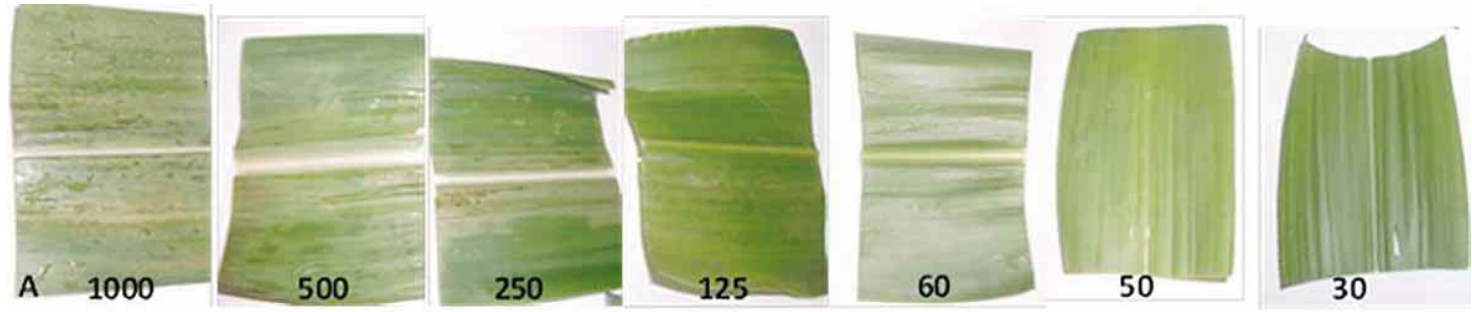

Fig. 1. Phytotoxicity test with corn leaf pieces with clove oil from India in the concentrations of 1000; 500; 250; 125; 60; 50 e $30 \mathrm{mg} / \mathrm{L}$ the DMSO. Classification: 1000 e 500 - phytotoxicity severe; 250 e 125 - phytotoxicity moderate; 60,50 e 30 - phytotoxicity mild. 
cages 10 X $15 \mathrm{~cm}$ (diameter and height) lined internally with paper for oviposition. Ten repetitions were performed for each treatment. The moths (adult stage of the armyworm) were fed $10 \%$ honey solution and kept in an acclimated chamber at $25.2 \pm 1.4^{\circ} \mathrm{C}$, relative humidity $67 \pm 0.7 \%$ and a photoperiod of $12 \mathrm{~h}$. Eggs were collected daily until the end of oviposition and placed in $10 \mathrm{~cm}$ diameter Petri dishes; the eggs subsequently were kept under the conditions described above. The total number of eggs and the number of viable eggs were counted. The data were subjected to analysis of variance and the averages were compared at a confidence interval of $95 \%$ probability $(\mathrm{p} \leq 0.05)$ using SAS software (SAS Institute, 2001).

\section{RESULTS}

The testes of control larvae were coated with connective tissue with invaginations that formed septa and divisions that delimited four testicular follicles (Fig. $2 \mathrm{~A})$. In the apical region of the follicle (germarium) numerous cysts were observed just below the germarium, which is characteristic of the growth zone. In the division and reduction zones (posterior to the growth zone) spermatids whose morphology ranged from oval to spherical were observed, and in the basal region of the follicle, transformation zone, numerous spermatozoids were observed (Figs. 2B-E).

After application of $50 \mathrm{mg} / \mathrm{ml}$ of clove oil, the number of cysts in the follicle was reduced, however, the lining and septa of the connective tissue of the testis did not differ

Fig. 3. Testis of $S$. frugiperda larva treated with $30 \mathrm{mg} / \mathrm{L}$ clove oil. A) Overview of the testis, Bar= $200 \mu \mathrm{m}$, Toluidine blue. B) Testicular coating detail, Bar= $100 \mu \mathrm{m}$, Toluidine blue. C) spermatids, Bar $=25 \mu \mathrm{m}$, Toluidine blue. D) Spermatozoid bundles, Bar $=100 \mu \mathrm{m}$, Toluidine blue. Arrow- connective tissue, arrowheadconnective tissue septum, c - cyst, star- oval spermatids, dashed arrow- spherical spermatids, es - spermatozoids.

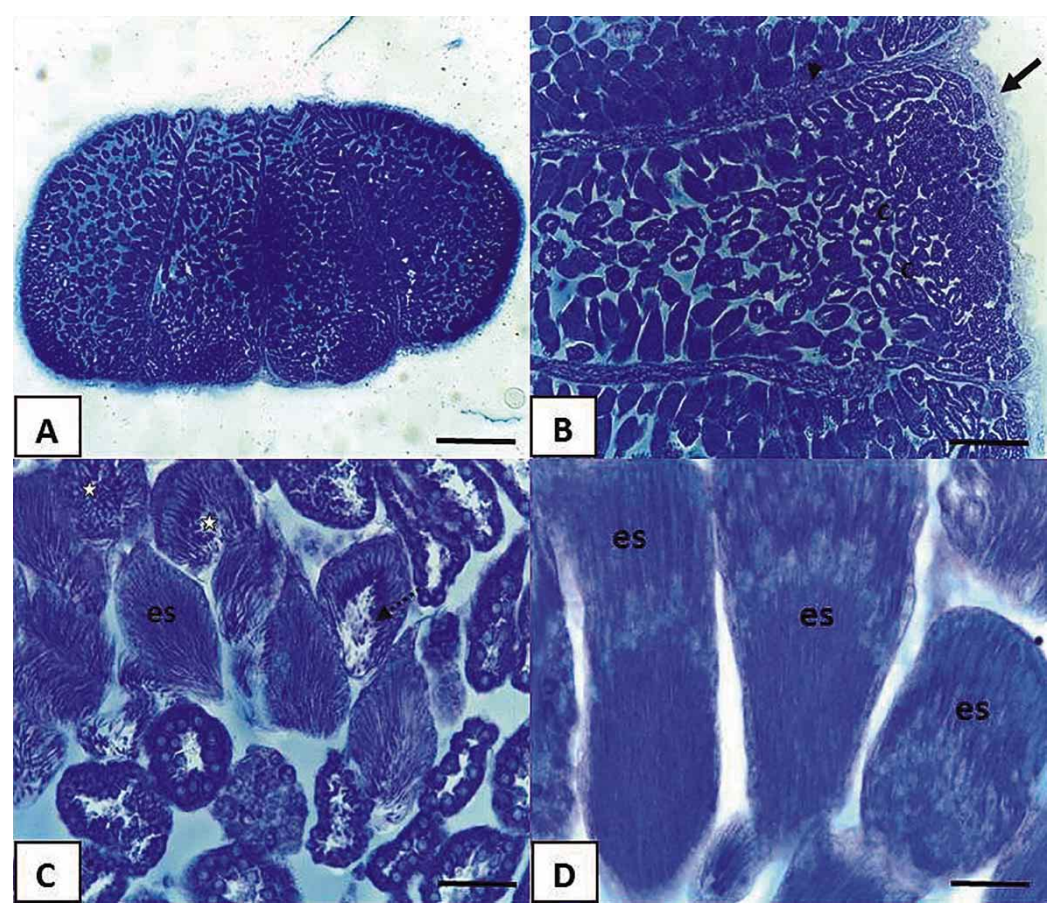

Fig. 2. Testes from $S$. frugiperda larva without treatment. A) Overview of the testes. Toluidine blue, Bar $=200 \mu \mathrm{m}$. B) Detail testicular coating; growth zone, reduction, division the transformation, Bar $=100 \mu \mathrm{m}$, Toluidine blue. C) Presence of spermatids, Bar $=25 \mu \mathrm{m}$, Toluidine blue. D) Bundles of spermatozoids, Bar $=25 \mu \mathrm{m}$, Toluidine blue. Arrow - connective tissue, c- cysts; $t$ - tracheoles, arrowhead - connective tissue septum, star - oval spermatids, dashed arrow- spherical spermatids, es spermatozoids.

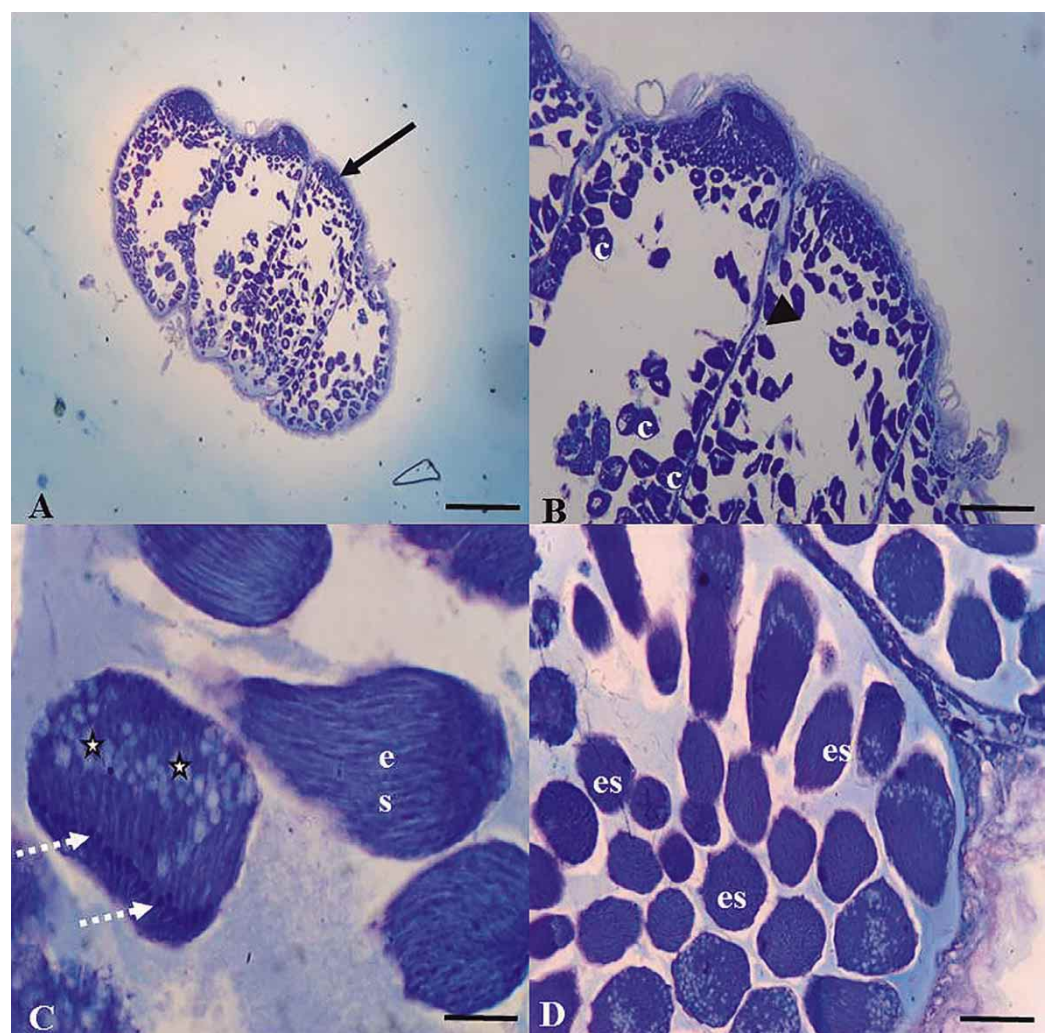


CRUZ, G. S.; TEIXEIRA, V. W.; DE OLIVEIRA, J. V.; TEIXEIRA, A. A. C.; ARAÚJO, A. C.; ALVES, T. J. S.; DA CUNHA, F. M. \& BREDA, M. O. Histological and histochemical changes by clove essential oil upon the gonads of Spodoptera frugiperda (JE Smith) (Lepidoptera: Noctuidae). Int. J. Morphol., 33(4):1393-1400, 2015.

from control (Fig. 3A-B). Several spermatids and spermatozoids were also observed (Figs. 3C-D).

The testes of control adult insects were coated externally by connective tissue, but it does not penetrate the organ to form septa, and consequently, did not present the follicles filled with spermatozoid bundles. Tracheoles and fat body were associated with the testes (Figs. 4A-B). There was a reduction in the numbers and dimensions of spermatozoid bundles in testes after treatment with either concentration of clove oil (Figs. 4 C-D).
Regardless of treatments, the ovarioles were coated by a thin sheath of connective tissue that covered the follicular cells. The vitellarium region was well developed in all of the treatments with clove oil. Nurse cells, characteristic of a polytrophic ovariole, were also observed among the oocytes in the ovariole (Figs. 5A-D).

The histochemical analyses by bromophenol blue staining revealed reduced protein content in the yolk of oocytes of females treated with the essential oil compared to controls (Figs. 6A and 6C). The PAS reaction also

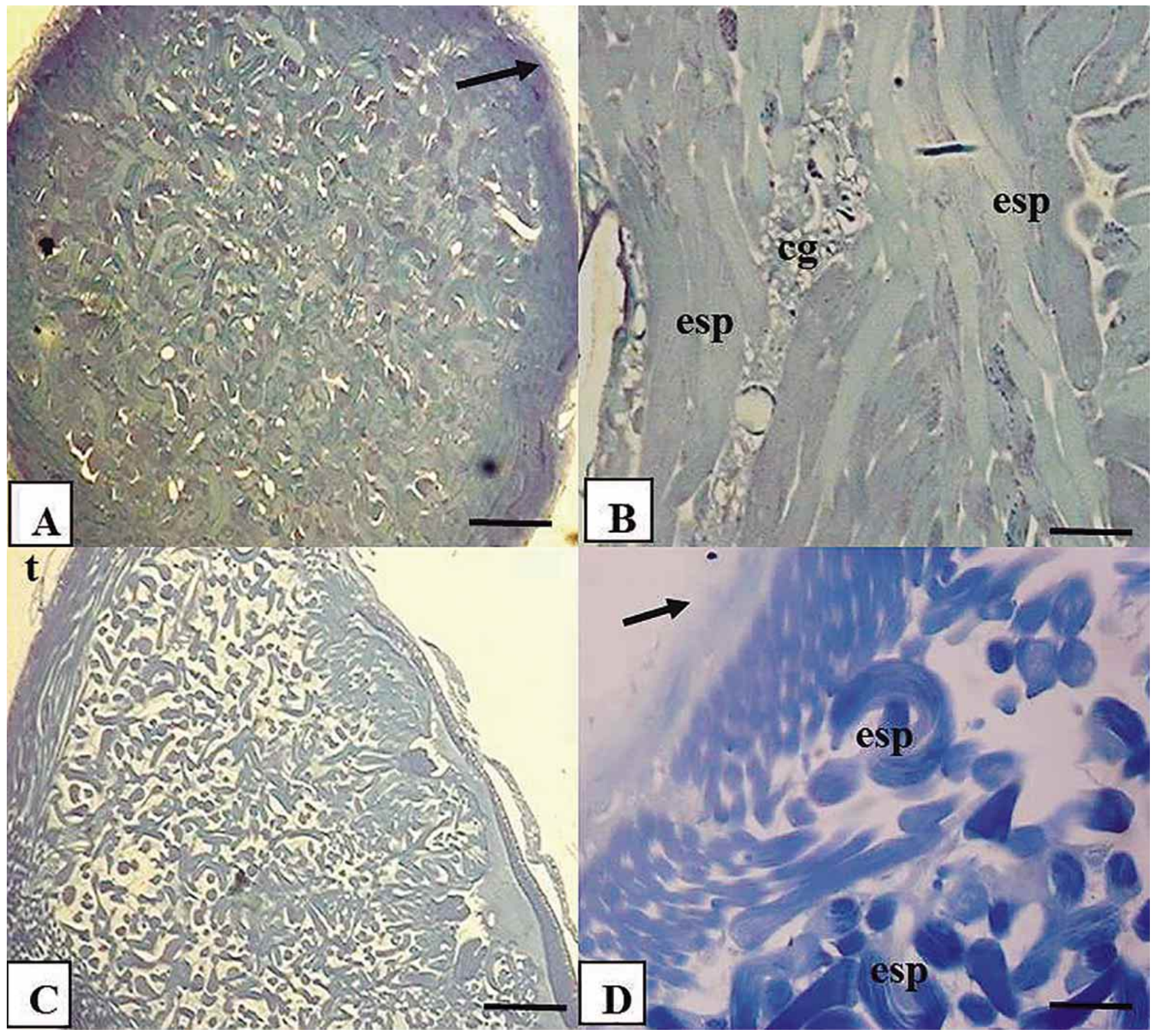

Fig. 4. Testicular S. frugiperda adult treated and control. A) General view of the testis without treatment, Bar= $200 \mu \mathrm{m}$, Toluidine blue. B) Control spermatozoid bundles, Bar $=100 \mu \mathrm{m}$, Toluidine blue. C) Note the abundance of traqueolas testicular surface control, Bar=200 $\mu \mathrm{m}$, Toluidine blue. D) fat body and Spermatozoid bundles control. E) testis clover oil treatments with $50 \mathrm{mg} / \mathrm{L}, \mathrm{Bar}=25 \mu \mathrm{m}$, Toluidine blue. Arrow - connective tissue, esp - spermatozoids, $\mathrm{t}$ - tracheoles, cg- fat body. 
CRUZ, G. S.; TEIXEIRA, V. W.; DE OLIVEIRA, J. V.; TEIXEIRA, A. A. C.; ARAÚJO, A. C.; ALVES, T. J. S.; DA CUNHA, F. M. \& BREDA, M. O. Histological and histochemical changes by clove essential oil upon the gonads of Spodoptera frugiperda (JE Smith) (Lepidoptera: Noctuidae). Int. J. Morphol., 33(4):1393-1400, 2015.

showed a reduction in the neutral carbohydrate content in the yolk of the larvae treated with $50 \mathrm{mg} / \mathrm{L}$ of clove oil, when compared to the control (Figs. 7D-F).
It was verified that in the tested concentrations, clove oil caused a significant reduction in the total number of eggs compared to the control, significantly affecting viability and the number of hatched larvae (Table I).

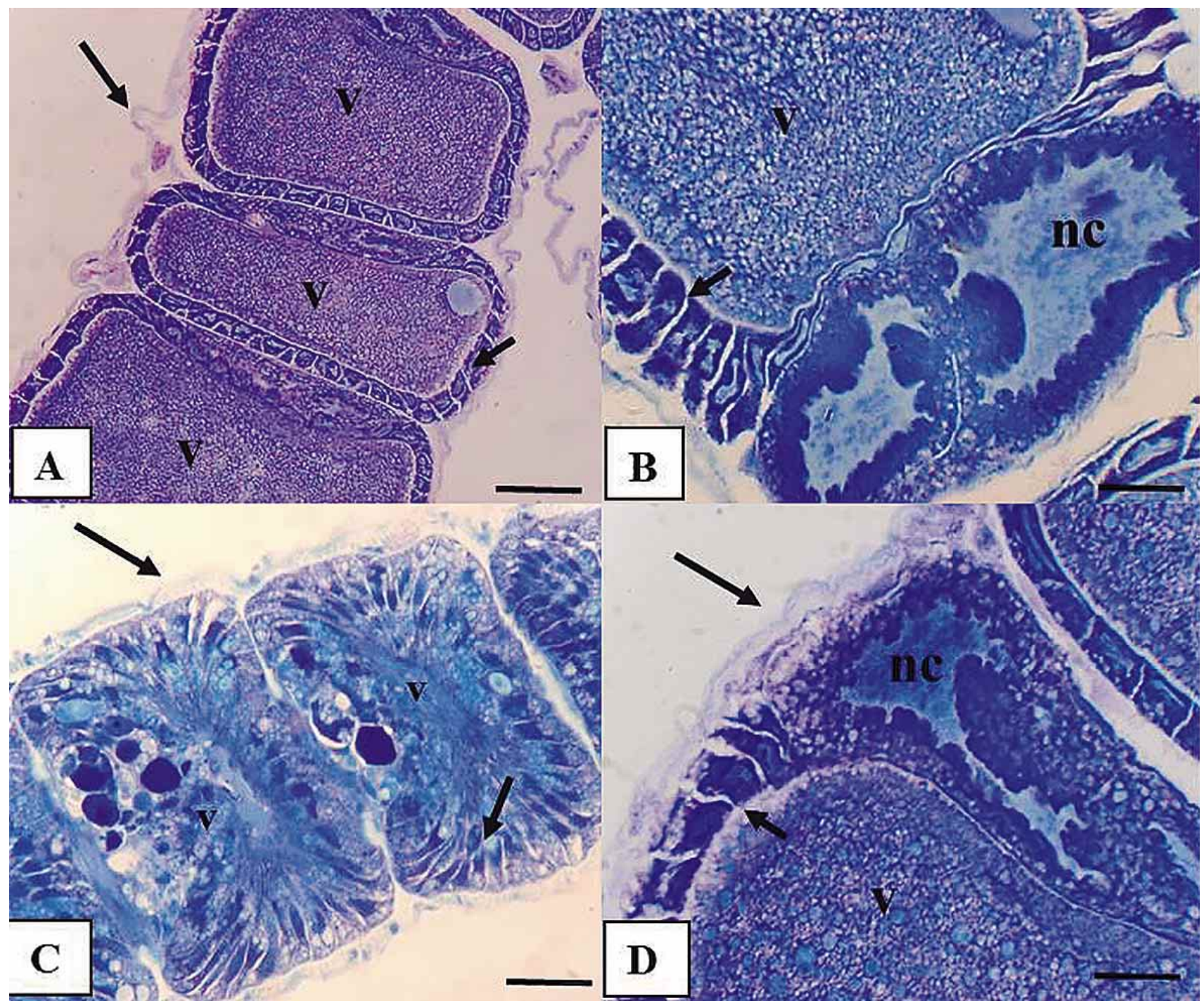

Fig. 5. Ovariole of a $S$. frugiperda adul: A and B) control, Bar $=100 \mu \mathrm{m}$ and $25 \mu \mathrm{m}$, respectively, Toluidine blue. C and D) Treated with clover oil concentration of $50 \mathrm{mg} / \mathrm{L}$. Bar $=100 \mu \mathrm{m}$, Toluidine blue. Arrow - sheath of connective tissue, short arrow - follicular cells, $\mathrm{v}$ - calf, cn - nurse cell.

Table I. Average total numbers of eggs and hatched eggs of Spodoptera frugiperda 3rd instar larvae treated with clove essential oil. Temp: $25.2 \pm 1.4$ ${ }^{\circ} \mathrm{C}, \mathrm{RH}: 67 \pm 0.7 \%$ and $12 \mathrm{~h}$ photophase.

\begin{tabular}{|c|c|c|}
\hline Treatment $(n=3)^{1}$ & $\operatorname{Eggs}( \pm \mathrm{SE})^{2}$ & Hatched $( \pm \mathrm{SE})^{2}$ \\
\hline Control & $1604.8 \pm 235.63^{\mathrm{a}}$ & $97.2 \pm 0.37^{\mathrm{a}}$ \\
\hline Clove $50 \mathrm{mg} / \mathrm{L}$ & $790.4 \pm 113.14 \mathrm{~b}$ & $87.4 \pm 1.43 \mathrm{~b}$ \\
\hline Statistics ${ }^{\mathrm{P}}$ & $13.380^{.0001}$ & $24.38^{0.0001}$ \\
\hline
\end{tabular}

$1 \mathrm{~N}=$ replication numbers.

2 Averages followed by the same letter do not differ by $t$ test at $5 \%$ probability. 


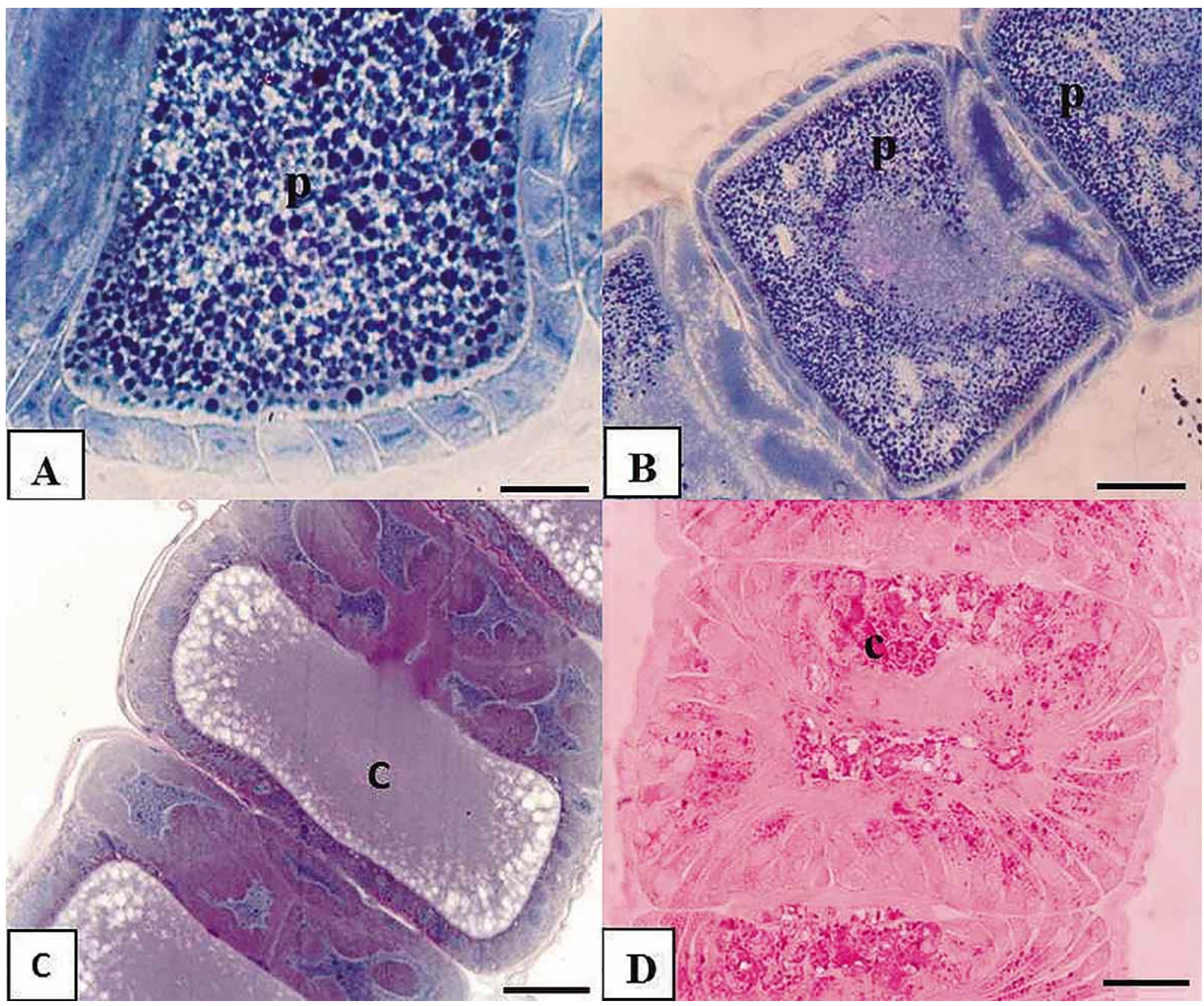

Fig. 6. Terminal portion of ovariole in S. frugiperda adults: A) Control, Bar $=100 \mu \mathrm{m}$, Bromophenol blue. B) Clover with dosages $50 \mathrm{mg} /$ L. C) Ovariole control submitted to the P.A.S., Bar= $100 \mu \mathrm{m}$. D) P.A.S. ovarioles the treatment with India clove oil on concentration 50 $\mathrm{mg} / \mathrm{L}$. p- protein and c - carbohydrate.

\section{DISCUSSION}

The use of plants with insecticidal properties have been applied as a viable and attractive alternative in integrated pest management programs, mainly, due to the range of effects over several biological, physiological and behavioral parameters of the target insects (Isman; Gallegos \& Maroneze).

The influence of the major compounds of clove oil with insecticidal properties (Raina et al., 2001), have also shown secondary effects in $S$. frugiperda, characterized by the interference in the spermatogenesis process by reducing the number of eggs laid. Similar results were found by Birah et al. (2010) and Alves et al. when using the extract of clove and long pepper, exhibiting a juvenoid action capable of affect the fertility and fecundity of Spodoptera litura (Lepidoptera: Noctuidae) and $S$. frugiperda, respectively. Moreover, similar effects were observed for the concentration of $50 \mathrm{mg} / \mathrm{L}$ of clove oil in this study. The reduced number of eggs and their viability in insects submitted to the clove oil, is probably associated with eating disorders, leading to negative effects on reproduction (Milano et al., 2010). 
According to Al-Jahdali \& Bisher (2007), Sayim (2007) the presence of vacuoles in cyst cells of testicular follicles in the larvae treated with clove oil suggests degeneration and reported that changes in membrane physiology can cause cytoplasmic vacuoles. As for the histochemical changes observed in females, concerning the protein content and neutral carbohydrates in ovarioles, it directly affects negatively the vitelogenesis for reproduction (Gillott, 2005; Sharma et al., 2011).

Physiological changes found in the reproductive system of the treated insects presumably are related to the deterrent property of clove, related to chemoreceptor substances, capable of blocking the phagostimulants, thus inhibiting feeding (Mordue \& Nisbet, 2000). Furthermore, the deterrence effect may result in morphological and physiological changes on the reproductive system, thus compromising the reproductive activities, since its development is exclusively dependent on the nutrients acquired in the immature stage for $S$. frugiperda (Milano et al.).

According to Costa et al. (2004) and Milano et al., the reduced number of eggs and their viability are important effects of essential oils on the reproduction of insects, because decreased reproduction rates usually are associated with eating disorders and nutritional deficiency. Engelman (1998) stated that the number of ovarioles could be altered by the quantity and quality of nutrients and secondary metabolites available to the ovarioles during differentiation, which would cause changes in vitellogenesis, ova maturation and egg production.

The results demonstrate that the use of clove essential oil in the $50 \mathrm{mg} / \mathrm{L}$ concentration affects spermatogenesis and the histochemistry of $S$. frugiperda ovarioles, reflecting in its reproduction, proving to be a promising option in controlling this pest, since reproduction is an important tool in population dynamics, being a success factor modulator of insect pests in crops.

CRUZ, G. S.; TEIXEIRA, V. W.; DE OLIVEIRA, J. V.; TEIXEIRA, A. A. C.; ARAÚJO, A. C.; ALVES, T. J. S.; DA CUNHA, F. M. \& BREDA, M. O. Alteraciones histológicas e histoquímicas provocadas por el aceite esencial de clavo de olor en las gónadas de Spodoptera frugiperda (JE Smith) (Lepidoptera: Noctuidae). Int. J. Morphol., 33(4):1393-1400, 2015.

RESUMEN: Spodoptera frugiperda es un insecto polífago que causa pérdidas económicas a varias cosechas en Brasil y es el mayor obstáculo para la producción de maíz. Este estudio está centrado en el control alternativo, con productos botánicos que se están expandiendo y ofrecen una amplia variedad de moléculas que interfieren con diferentes parámetros biológicos de plagas de insectos. Por tanto, se puso a prueba la hipótesis de que el aceite esencial de clavo de olor afecta la espermatogénesis. La histoquímica de los ovarioles y la fertilidad de $S$. frugiperda. Los resultados mostraron que el aceite esencial de clavo de olor afecta la gametogénesis de los ovarioles en $S$. frugiperda, lo que incide negativamente en su reproducción, demostrando ser una herramienta prometedora para el control de esta plaga.

PALABRAS CLAVE: Gusano cogollero; Spodoptera frugiperda; Reproducción; Histoquímica; Histologia; Syzygium aromaticum.

\section{REFERENCES}

Abdel-Rahman, A. G.; El-Sayed, A. K.; Laila, S. H. \& Imam, A. I. Histological alternations in male testis of Pectinophora Gossypiella (S.) adults induced by treating larvae with neem formulations. Cairo, 1st Arab Conference of Applied Biological Pest Control, 2004. pp.764.

Al-Jahdali, M. O. \& Bisher, A. S. B. Testicular histopathological alterations in rats treated with sumithion ${ }^{\circledR}$ NP 25/2.5 EC, insecticide. J. Biol. Sci., 7(3):520-5, 2007.

Alves, T. J.; Cruz, G. S.; Wanderley-Teixeira, V.; Teixeira, A. A.; Oliveira, J. V.; Correia, A. A.; Câmara, C. A. \& Cunha, F. M. Effects of Piper hispidinervum on spermatogenesis and histochemistry of ovarioles of Spodoptera frugiperda. Biotech. Histochem., 89(4):245-55, 2014.
Birah, A.; Sharma, T. V. R. S.; Singh, S. \& Srivastava, R. C. Effect of aqueous leaf extract of cloves (Syzygium aromaticum) on growth and development of tobacco caterpillar (Spodoptera litura). Indian J. Agric. Sci., 80(6):534-7, 2010.

Costa, E. L. N.; Silva, R. F. P. \& Fiusa, L. M. Efeitos, aplicações e limitações de extratos de plantas inseticidas. Acta Biol. Leopoldensia, 26(2):173-85, 2004.

Cruz, I.; Figueiredo, M. L. C. \& Matoso, M. J. Controle biológico de Spodoptera frugiperda utilizando o parasitóide de ovos Trichogramma. Sete Lagoas, EMBRAPA-CNPMS, 1999.

Engelmann, F. In vitro germplasm conservation. Acta Hortic., (461):41-7, 1998. 
CRUZ, G. S.; TEIXEIRA, V. W.; DE OLIVEIRA, J. V.; TEIXEIRA, A. A. C.; ARAÚJO, A. C.; ALVES, T. J. S.; DA CUNHA, F. M. \& BREDA, M. O. Histological and histochemical changes by clove essential oil upon the gonads of Spodoptera frugiperda (JE Smith) (Lepidoptera: Noctuidae). Int. J. Morphol., 33(4):1393-1400, 2015.

Frans, R.; Talbert, R.; Marx, D. \& Crowley, H. Experimental design and techniques for measuring and analysing plant responses to weed control practices. In: Camper, N. D. (Ed.) Research Methods in Weed Science. 3rd ed. Champaign, Southern Weed Science Society, 1986

Gallegos, D. M. N. \& Maroneze, D. M. Efeito de extrato aquoso de Melia azedarach no desenvolvimento das fases imatura e reprodutiva de Spodoptera frugiperda (J. E. Smith, 1797) (Lepidoptera: Noctuidae). Semina Ciênc. Agrar., 30(3):53750, 2009.

Gillott, C. Entomology. 3rd ed. Dordrecht, Springer, 2005.

Habluetzel, A.; Carnevali, F.; Lucantoni, L.; Grana L.; Attili, A. R; Archilei, F.; Antonimi, M.; Valbonesi, A.; Abbadessa, V.; Esposito, F. \& van der Esch, S. A. Impact of the botanical insecticide Neem Azal on survival and reproduction of the biting louse Damalinia limbata on angora goats. Vet. Parasitol., 144(3-4):328-37, 2007.

Isman, M. B. Botanical insecticides, deterrents, and repellents in modern agriculture and an increasingly regulated world. Апnи. Rev. Entomol., 51:45-66, 2006.

Lima, M. P. L.; Oliveira, J. V. \& Marques, E. J. Manejo da lagartado-cartucho em milho com formulações de nim e Bacillus thuringiensis subsp. aizawai. Ciên. Rural, 39(4):1215-18, 2009.

Milano, P.; Filho, E. B.; Parra, J. R. P.; Oda, M. L. \& Cônsoli, F. L. Efeito da alimentação da fase adulta na reprodução e longevidade de espécies de Noctuidae, Crambidae, Tortricidae e Elachistidae. Neotrop. Entomol., 39(2):172-80, 2010.

Mordue, A. J. \& Nisbet, A. J. Azadirachtin from the neem tree Azadirachta indica: its action against insects. An. Soc. Entomol. Brasil, 29(4):615-32, 2000.

Oliveira, M. S. S.; Roel, A. R.; Arruda, E. J. \& Marques, A. S. Efficience of extracts of plants in control of fall armyworm in corn Spodoptera frugiperda (J.E. Smith, 1797) (Lepidoptera: Noctuidae). Ciênc. Agrotec., 31(2):326-31, 2007.

Raina, V. K.; Srivastava, S. K.; Aggarwal, K. K.; Syamasundar, K. V. \& Sushil Kumar. Essential oil composition of Syzygium aromaticum leaf from Little Andaman, India. Flav. Frag. J., 16(5):334-6, 2001.

SAS Institute. SAS/STAT User's Guide. Version 8.02, TS level 2MO. Cary, SAS Institute Inc., 2001.

Sayim, F. Histopathological effects of dimethoate on testes of rats. Bull. Environ. Contam. Toxicol., 78(6):479-84, 2007.

Senthil Nathan, S.; Young Choi, M.; Yul Seo, H.; Hoon Paik, C.; Kalaivani, K. \& Duk Kim, J. Effect of azadirachtin on acetylcholinesterase (AChE) activity and histology of the brown planthopper Nilaparvata lugens (Stål). Ecotoxicol. Environ. Saf., 70(2):244-50, 2008.
Sharma, P.; Mohan, L.; Dua, K. K. \& Srivastava, C. N. Status of carbohydrate, protein and lipid profile in the mosquito larvae treated with certain phytoextracts. Asian Pac. J. Trop. Med., 4(4):301-4, 2011.

Shehata, N. F.; Younes, M. W. F. \& Mahmoud, Y. A. Histopathological effects of gamma irradiation on the peach fruit fly, Bactrocera Zonata (Saund) male gonads. J. Apl. Sci. Res., 2(11):1053-8, 2006.

Silvestri, J. D. F.; Paroul, N.; Czyewski, E.; Lerin, L.; Rotava, I.; Cansian, R.L.; Mossi, A.; Toniazzo, G.; Oliveira, D. \& Treichel, H. Perfil da composição química e atividades antibacteriana e antioxidante do óleo essencial do cravo-da-índia (Eugenia caryophyllata Thunb). Rev. Ceres, 57(5):589-94, 2010.

\author{
Correspondence to: \\ Glaucilane dos Santos Cruz \\ Department of Animal Morphology and Physiology \\ Federal Rural University of Pernambuco \\ Dom Manoel de Medeiros street, s/n Dois Irmãos \\ CEP 52171-900 \\ Recife-PE \\ BRAZIL
}

Email: nanebiologa@hotmail.com

Received: 20-05-2015

Accepted: 23-09-2015 